\title{
EN SERIØS SPROGTEORETISK FIKTIONALITETSDEFINITION
}

\begin{abstract}
A SERIOUS LINGUISTIC DEFINITION OF FICTIONALITY | Fiction is often defined in terms of "something which does not exist" or "something related to art". Richard Walsh, however, uses the term "fictionality" to describe a phenomenon which is not just seen as opposed to reality and not limited to generic genres such as movies, novels and short-stories. Fictionality is a feature which is not only ascribed to what we normally categorize as fiction, but something which also exists within the frame of everyday communication (Walsh 2007). Richard Walsh expounds many of the benefits which derive from using the notion of fictionality, but does not come up with an exact definition of the concept. At one point, Walsh considers the idea of viewing fictionality as an indirect speech act as proposed by Gérard Genette. Due to two significant problems related to Genette's theory, Walsh dismisses the idea of fictionality as an indirect speech act, even though he acknowledges its potential. This article's point of departure is Genette's definition of fiction. It points out that Genette's concept of fiction relies on J.R. Searles idea of fiction, even though Genette operates with a different definition. The article agrees with the criticism Walsh puts forward but argues that it is possible to compensate for the problems in Genettes theory and thereby hold on to the idea of fictionality as an indirect speech act. Furthermore, the article points out that considering fictionality as an indirect speech act contributes to an explanation of what distinguishes fictionality.
\end{abstract}

KEYWORDS I Genette, Searle, Walsh, fiction, fictionality, indirect speech act, narrator, author, contextuality, sender-receiver relationship

De seneste årtiers sammenblandinger af begreber som værk, forfatter, fiktion og (selv)biografi har kaldt på et nyt fiktionsbegreb. Et sådant tilbyder Richard Walsh i The Rhetoric of Fictionality (2007). Walsh beskriver heri begrebet "fiktionalitet" som en egenskab ikke blot ved alle såkaldte generiske fiktionsgenrer, men som noget, der også kan forekomme inden for andre genrer og integreret i sproget i den virkelige verdens kommunikative handlinger (Walsh).

Richard Walshs fiktionalitetsteori har dannet baggrund for flere nye teoretiseringer i dansk kontekst. I dobbeltnummeret af Spring - Fiktionens forandringer tager flere af artikelforfatterne eksplicit udgangspunkt i Richard Walsh og hans bestemmelse af fiktionalitet som et retorisk og ikke generisk afgrænset fænomen. Rolf Reitan peger endda på, at Walsh repræsenterer begyndelsen til et nyt paradigme (Reitan 52). 
Mens Walsh åbner for en bred fiktionsforståelse, definerer han imidlertid ikke begrebet fiktionalitet præcist. Denne artikel vil give et bud på, hvordan fiktionalitet kan defineres ud fra talehandlingsteorien. Tidligere sprogteoretiske forsøg på at beskrive fiktion har bygget på negative bestemmelser og har anskuet fiktion som noget ikke-seriøst, men denne artikel vil betragte fiktionalitet som en seriøst ytret talehandling. Artiklen vil argumentere for, at en adækvat måde at bestemme fiktionalitet på er via den indirekte talehandling, og at en sådan anskuelse kan forklare mange af de både teoretiske og empiriske problematikker, der er knyttet til de igangværende diskussioner om opfattelser af fiktion.

\section{Fiktion som en indirekte talehandling}

Walsh henviser i The Rhetoric of Fictionality til Gérard Genettes artikel "The Pragmatic Status of Narrative Fiction", hvor Genette definerer fiktion som en indirekte talehandling. Genette skriver: "For mig at se er det rimeligt at beskrive intentionelt fremsatte fiktive ytringer som ikke-seriøse (eller ikke-bogstavelige) assertioner, der i form af indirekte talehandlingstyper (eller figurer) dækker over eksplicitte fiktive deklarationer (eller anmodninger)" (Genette 59-73'). Walsh opholder sig kun kort ved Genettes teori, fordi han ser to problematiske aspekter ved den fiktionsdefinition, Genette når frem til:

Walsh fremfører, at hvis fiktive ytringer, ${ }^{2}$ som Genette skriver, er indirekte talehandlinger, må de gøre noget andet end blot at indstifte en fiktiv verden.

For det andet, skriver Walsh, må fiktionaliserede ytringer være seriøst ytrede. Hvis fiktionaliserede ytringer har en indirekte illokutionær kraft, må den direkte ytrede talehandling, gennem hvilken de opnår denne, ikke bare være "foregivet", men seriøs (Walsh 76).

Til trods for disse indvendinger skriver Walsh, at han ikke vil modsætte sig ideen bag Genettes definition:

”Jeg vil ikke afvise ideen bag forsøget på at forstå fiktioner som indirekte talehandlinger: de store linjer i Genettes redegørelse peger hen mod fiktionalitetens relevansmodel, som jeg har fremsat i kapitel et. Men modellen kræver, at fiktionelle ytringer er seriøse talehandlinger fra forfatterens side.” (Walsh 78)

Fiktion må, som Walsh skriver, anskues som en seriøst ytret talehandling. Denne artikel vil argumentere for, at fiktionalitet kan anskues som indirekte talehandling, der er seriøst ytret. Artiklen vil anskueliggøre, at problemet ved Genettes teori om fiktion som en indirekte talehandling ikke angår definitionen i sig selv, men det

I Genettes artikel "The pragmatic status of narrative fiction" foreligger gennem Aarhus Statsbiblioteks database-service kun på ebscohost.com i HTML-format, hvor præcist sidetal ikke er medtaget. Referencen til artiklen vil i det følgende derfor foregå på lignende vis.

2 Betegnelsen "ytringer" dækker i artiklen både over tekstuelle og mundtlige ytringer. 
faktum, at Genette gør brug af J.R. Searles fiktionsteori, selvom han opererer med en anden definition.

\section{Fiktion anskuet som ikke-seriøs talehandling - Searles talehandlingsteori}

Searle tager i "A Classification of Illocutionary Acts" afsæt i Austins talehandlingsteori, men anlægger sin egen, der består af fem talehandlingstyper: assertiv, direktiv, kommissiv, ekspressiv og deklaration (Searle (3)). Han specificerer tre former for basis-taksonomier til at klassificere talehandlingstyperne/de illokutionære handlinger ${ }^{3}$ med:

I. Illokutionært formål (illocutionary point/purpose)

2. Tilpasningsretning (direction of fit)

3. Den udtrykte psykologiske tilstand (expressed psychological state) (Searle (3) I).

Formålet angår, hvad afsenderen ${ }^{4}$ gerne vil opnå med den ytrede talehandlingstype. Tilpasningsretningen angår, hvorvidt illokutionen retter sig mod at få ordene til at passe til verdenen (assertiv), verdenen til at tilpasse sig ordene (kommissiv og direktiv), ingen af delene (ekspressiv) eller begge dele (deklaration). Afsender af enhver illokutionær handling udtrykker, ifølge Searle, desuden en psykologisk tilstand, der også indgår i hans klassifikationssystem. Til den assertive talehandlingstype knytter Searle afsenderens tiltro til eller tro på det, denne ytrer. Han fremhæver, at afsender f. eks. ikke kan sige: "Jeg hævder at p er, men jeg tror ikke rigtig på p", fordi afsenderen da samtidig afslører sig selv som bedragerisk. Det er tilsammen disse tre taksonomier, der danner basis for klassifikationen af talehandlingstyperne, men Searle skriver om det tredje taksonomiske niveau, der angår afsenderens psykologiske tilstand, at en analyse udelukkende baseret på dette kan føre langt (Searle (3) 4).

I "The Logical Status of Fictional Discourse" bestemmer Searle fiktion ud fra sin talehandlingsteori. Searle erklærer, at fiktion er en "ikke-seriøs" talehandling, men hans begrundelse bygger udelukkende på det sidste taksonomiske niveau: det, der angår afsenderens psykologiske tilstand. Searle bestemmer fiktionen som ikkeseriøs talehandling ud fra en antagelse om, at den er en assertiv talehandlingstype, og at afsenderen derfor ikke lever op til oprigtighedskriterierne, når denne siger noget, der ikke stemmer overens med forholdene i den virkelige verden (Searle (I)).

Genettes bestemmelse af fiktion som ikke-seriøs talehandlingstype bunder i, at han overtager Searles karakterisering af fiktion. Som påpeget, er Searles beskrivelse af fiktion som ikke-seriøs imidlertid grundet $i$, at han anskuer fiktion som udtrykkene synonymt.

4 Da fiktionalitet skal forstås som et begreb ikke kun knyttet til bestemte kontekster, bruges i artiklen de tilsvarende brede begreber "afsender" og "modtager". 
en forfejlet assertiv talehandlingstype. Genette bestemmer fiktion som en indirekte talehandling i form af en assertiv med en indirekte deklaration og definerer dermed fiktion anderledes end Searle. Genette har, fordi den talehandlingstype, han bruger til at beskrive fiktion, er en anden end Searles, derfor reelt ikke grundlag for at karakterisere fiktionen som ikke-seriøs ud fra Searles bestemmelser. Hermed vil jeg hævde, at det forste problematiske aspekt, Walsh (med rette) påpeger hos Genette, ikke ligger i Genettes egen bestemmelse af fiktion som en indirekte talehandling, men i Searles teori, der tager udgangspunkt i, at fiktion udelukkende skulle være en (ikke-seriøs) assertiv talehandlingstype.

\section{Fortceller-problematikken}

Et afgørende fejlgreb, der bliver resultatet af at karakterisere fiktion som en ikkeseriøs "laden som om”, angår fortælleren i fiktion. Searle skriver: ”I førstepersonsnarrationer lader forfatteren ofte, som om at han/hun er en anden, der fremsætter assertioner" (Searle (I) 328). Genette fører dette aspekt fra Searles teori videre i sin egen, idet han skriver, at forfatteren altid lader, som om han/hun er en karakter i det fiktive univers. Et af de problematiske aspekter, dette afstedkommer, er, som Walsh påpeger, at fiktion anskuet som noget foregivet kræver én, der skal "foregive” eller "lade som om". I opposition til dette fremfører Walsh, at forfattere ikke lader som om, de er fortællende karakterer, men repræsenterer karakterer. Searles og Genettes antagelse om "laden som om" fører, som Walsh skriver, til en unødvendig fordobling af udsigelsespositionen, der alene tjener til at etablere en repræsentationel ramme, hvor det fortalte kan blive læst som en rapportering frem for en opfindelse. Hvis fortælleren anskues som den, der inden for værkets rammer har kendskab til det, der foregår, og dermed blot rapporterer, annulleres fiktionaliteten (Walsh 77-78). Walsh bryder med det, der har været paradigmet inden for litteraturteori i årtier: ideen om en fast fortæller, der er den berettende instans i fiktion. Walsh skriver: "Svaret på mit oprindelige spørgsmål, ”hvem er fortælleren?” er dette: fortælleren er altid enten en karakter, der fortæller, eller forfatteren" (Walsh 78). Jeg mener, Walsh peger på noget helt afgørende ved at fremhæve, at en uafhængig fortællerinstans ikke har nogen berettigelse, da fortælleren blot fungerer som en fordoblende instans af forfatteren. Dog vil jeg samtidig påpege det problematiske $i$, at Walsh fremhæver fortælleren som værende enten en karakter eller forfatteren. I denne formulering udlægger Walsh fortællerproblematikken, så det fremstår, som om en fiktiv karakter er på samme ontologiske niveau som forfatteren, hvilket tillader, at de på lige fod kan påtage sig "fortællerrollen".

I samme artikel af Genette, som Walsh fremsætter sine indvendinger imod, skriver Genette, at den, der fortæller i en homodiegetisk fortælling, altid vil være på samme niveau som de øvrige karakterer i fiktionen. Konsekvensen af dette er, som han skriver, at talehandlingerne fra fortællerens side derfor også kun vil være på niveau med fiktionen og dermed kun "fiktivt" seriøse: 
"I den slags fortælling, der rubriceres som "personal" (Ryan) eller "første-persons"(i narratologiske termer som en "homodiegetisk" fortælling), er den, der taler i fortællingen, selv en karakter i fortællingen (det er den eneste rammende betydning, der kan tillægges udtrykket "første-person”), han er selv fiktiv og som konsekvens af det, er hans talehandlinger som fortæller lige så fiktivt seriøse som dem fra de andre karakterer i historien.” (Genette 59-73)

Denne betragtning er, som jeg ser det, også en potentiel fare ved Walshs formulering, når han betragter fortælleren som enten en karakter eller forfatteren. Den første mulighed: At det er en karakter, der er fortælleren, implicerer det, som Genette hævder, nemlig, at udsigelsesinstansen må være fiktiv og dermed på samme niveau som de øvrige karakterer i romanen. Det forhindrer, at der sker en kunstig fordobling i udsigelsesinstansen, men det er problematisk med en teori, der lader en fiktiv karakter bære fortællerinstansen, når der tilstræbes en forståelse for, hvordan fiktionaliseringer italesættes i en kommunikativ sammenhæng. Jeg vil forfægte en revurdering af Walshs formulering og i stedet erklære, at den, der fortæller, altid er forfatteren. Forfatteren kan da vælge at fortælle gennem brug af forskellige udsigelsesmodi.

\section{Fra deklarativ til indirekte talehandling}

Det andet aspekt, Walsh fremhæver som problematisk ved Genettes bestemmelse (ud over de misforhold, det afstedkommer at se fiktion som ikke-seriøs), er, at hvis fiktive ytringer er indirekte talehandlinger, må de gøre mere end blot at indstifte en fiktiv verden (Walsh 76). I stedet for en undersøgelse af, hvad fiktioner kan mere end at indstifte en fiktiv verden, er Genettes bestemmelse af fiktion snarere en afgrænsning af, hvad fiktion som deklarativ talehandling formår.

Tidligere definitioner af fiktion som en deklarativ talehandling har været forgængere for en negativ fiktionalitetsopfattelse. J.L. Austin lagde med How to do things with words (I962) grunden for talehandlingsteorien, men definerede samtidig fiktion som en ikke-seriøs talehandling. Alligevel blev Austins talehandlingsteori af flere teoretikere benyttet til at beskrive litteratur. I sit kritiske essay "Forfatterens død” skriver Roland Barthes: "Det er fordi (eller det følger at), det at skrive ikke længere kan betegne en operation, der registrerer, konstaterer, repræsenterer, der 'afbilleder' (som Klassikerne sagde), men snarere er, hvad lingvisterne i kølvandet på Oxford-filosofien kalder en performativ"s (Barthes 179). Barthes karakteriserer det som et negativt træk ved litteraturen, at den, som han ser det, har flyttet sig fra en art ren beskrivende assertiv til en performativ talehandlingstype. Wolfgang Iser tager i sin bestemmelse af litteratur ligesom Barthes udgangspunkt i J.L. Austins

5 Barthes bruger betegnelsen performativ, hvilket i Austins terminologi svarer til det, Searle, Genette og Walsh benævner deklarativ talehandlingstype. Se også fodnote 8. 
talehandlingsteoretiske skelnen mellem konstativer og performativer. ${ }^{6}$ Iser erklærer: "Det er klart, at litterære tekster hører til den sidste gruppe. De svarer ikke nøjagtigt til noget objekt i 'den virkelige verden', men skaber først deres objekter af elementer, som forefindes i 'den virkelige verden'” (Iser Io6).

Både Barthes og Iser fremhæver den litterære teksts berøring med den performative talehandlingstype. Iser skriver videre, at der må foretages endnu en differentiering, idet den litterære teksts status er af en anden type end de "sædvanlige" performative(/deklarative) talehandlingstyper som f. eks. lovtekster, der gælder som forpligtende normer i menneskers omgang med hinanden. Han skriver: "I modsætning hertil kan en litterær tekst aldrig frembringe sådanne sagsforhold. Det kan altså ikke undre, at man betegner disse tekster som fiktion, for fiktion er form uden realitet" (Iser I06). Iser indsncevrer dermed karakteriseringen af litteratur i forhold til performative(/deklarative) talehandlinger i en ikke-litterær kontekst, fordi de litterære ikke skaber normbaserede og lovmæssige ændringer i "den virkelige verden".

Genette er i sin distinktion af fiktion inde på noget af det samme som Iser. Han forklarer forskellen mellem "almindelige" deklarationer og deklarationer, der knyttes til fiktion på følgende måde: "Forskellen mellem sådan en deklaration [fiktionens] og den almindelige deklaration er tydeligvis den imaginære kvalitet af begivenheden "deklarerede": det vil sige, indholdet af p er ikke i forfatterens magt at forårsage (Genette 59-73). Denne bestemmelse gør, at Genette når frem til, at indirekte deklarative talehandlinger blot skaber en ny fiktiv verden. Han fokuserer dermed ikke, som Walsh efterspørger, på, hvad fiktionalitet som indirekte talehandling kan mere end at skabe en fiktiv verden, men derimod på, hvordan den formår mindre end at ændre noget i den "virkelige” verden.

Et andet sted skriver Genette, at det er fiktionens formål at blive anerkendt som fiktion, og som Walsh påpeger, er der diskrepans mellem det, at Genette mener, at forfatteren med sin indirekte deklarative talehandlingstype skaber en fiktionsverden og andetsteds i artiklen erklærer, at det er et succeskriterium for fiktionens illokution, at den fiktive intention erkendes (Walsh 76).

Jeg mener, at Genettes tvetydighed beror på, at han definerer fiktion som indirekte talehandling, men ikke tager konsekvensen af det. Med et lingvistisk og talehandlingsbaseret udgangspunkt er fiktion betragtet som en ikke-seriøs talehandling udledt af at definere fiktion alene som en assertiv talehandling, mens fiktion betragtet som noget, der ikke har andet formål end at indstifte fiktive verdener, er udledt af at definere fiktion alene som en deklarativ talehandling. Forklares fiktionalitet ud fra bestemmelserne for den indirekte talehandling, kan der imidlertid opnås en bedre forståelse for fiktionalitet anskuet som en egenskab.

6 Austin skelner i første omgang overordnet mellem disse to talehandlingstyper, men revurderer senere sin teori, idet han når frem til, at alle talehandlinger reelt er performative. Brugen af termen performativitet, Iser her benytter, svarer til den talehandlingstype, Searle klassificerer som deklaration. 


\section{Kommunikativ fiktionalitetsforståelse}

I artiklen "Indirect Speech Acts", hvor Searle karakteriserer den indirekte talehandling, skriver han, at afsenderen ved udførelsen af en indirekte talehandling ikke bogstaveligt talt mener det, han siger, eller at han mener mere end det, han siger. Indirekte talehandlinger indeholder på én gang to forskellige illokutionære kræfter: "[...] disse sætninger, der har en illokutionær kraft som del af deres betydning, kan bruges til at udføre en handling med en anden illokutionær kraft" (Searle (2) 7I). Det mest kendte eksempel fra Searles artikel er, at ytringen "Kan du nå saltet?", der er udformet som et spørgsmål, reelt kan bruges som en anmodning om at få overrakt saltet (Searle (2)). Den indirekte talehandlings form er dermed, at den ytres som én type talehandling, men samtidig indebærer en anden. Dens vellykkethed afhænger, skriver Searle, i første omgang af, om hensigten med talehandlingen erkendes af modtageren (Searle (2)).

Forklaret ud fra vellykkethedsbetingelserne for den indirekte talehandling, vil fiktionalitetens vellykkethed således $i$ forste omgang bero på, om modtager gennemskuer den indirekte talehandling, der ligger under den assertive talehandling, afsender har gjort brug af. Ligesom den indirekte talehandling "Kan du nå saltet?" i første omgang er vellykket, hvis modtager forstar, at afsender ønsker at kommunikere en anmodning, er fiktionalitet i første omgang vellykket, når modtageren forstår, at afsender ønsker at kommunikere, at der er tale om fiktionalitet. Eksempelvis er fiktionaliteten i sætningen "For mange år siden levede en kejser, som holdt så uhyre meget af smukke nye klæder" fra H.C. Anderens eventyr "Kejserens nye klæder" vellykket, hvis modtager forstår, at der ikke er tale om en direkte assertiv erklæring om en virkelig eksisterende kejser, men en indirekte deklaration om en fiktiv kejser.

Anskuelsen af fiktionalitet som en indirekte talehandling støtter op om flere afgørende aspekter ved Richard Walshs fiktionalitetsteori. I The Rhetoric of Fictionality videreudvikler Walsh perspektivet i H.P. Grices maksimeteori i retningen af dens betydning for fiktion. Ifølge Grice konstituerer maksimerne det samarbejdsprincip, der er fundamentet for succesfuld kommunikation. Efterfølgende har Dan Sperber og Deirdre Wilson argumenteret for, at Grices maksime om sandhed er underordnet relevans-maksimet. Ifølge Sperber og Wilson er det for modtageren vigtigere om det, der ytres, er relevant, end om det er sandt. Walsh adapterer denne teori og overfører den på fiktion. Walsh erklærer: "[...] fiktionalitetsproblemet er, når alt kommer til alt, ikke et spørgsmål om sandhed, men et spørgsmål om relevans. Det er antagelsen af relevans, ikke nogen forventning om bogstavelig sandhed, der leder læseren til at søge efter en passende fortolkningskontekst” (Walsh 30).

Walshs opprioritering af relevansmaksimen er særligt interessant i forhold til indirekte talehandlinger. I "Indirect Speech Acts" fremhæver Searle netop relevansmaksimen som helt afgørende for, at modtager forstår og ikke blot afviser en indirekte talehandling. En indirekte talehandling er kendetegnet ved ikke at have åbenlys relevans for den kontekst, den indgår i, og derfor kræver den i særlig grad, 
at modtageren søger efter en relevant kontekst at indskrive den i (Searle (2)). På den måde bliver Walshs forskydning fra sandheds- til relevansmaksimen $i$ forhold til fiktionalitet ekstra redundant med en opfattelse af fiktionalitet som en indirekte talehandling.

Searle behandler i "Hvad er en talehandling”, hvilke markører der gør, at forskellige illokutionære talehandlingstyper bliver opfattet som værende netop den pågældende type talehandling. Disse kalder han de "funktions-indicerende markører". De indbefatter ting som: ordfølge, tryk, intonationskontur, tegnsætning, verbets modus og performative verber. Hvordan man forstår den indirekte talehandling afhænger, som Searle skriver, af lingvistisk så vel som nonlingvistisk baggrundsinformation samt rationalitet og inferens fra både afsender og modtager. Forståelsen af en indirekte talehandling kræver, at modtager søger dens relevans ud over det bogstaveligt formulerede (Searle (2) 6o-6I). Dertil skriver Searle, at det samme propositionelle indhold kan være fælles for alle arter af illokutionære handlinger, og derfor bør man adskille analysen af det propositionelle indhold fra analysen af arten af illokutionen (Searle (2)).

Dette andet aspekt ved den indirekte talehandling er ligeledes særdeles brugbart i forhold til en kommunikativ forståelse af fiktionalitet. Hvis fiktionalitet anskues som indirekte talehandlingstype, kan fiktionalitet ud fra Searles beskrivelse af talehandlingstyper godt være bærer af det samme propositionelle indhold som noget ikke-fiktionaliseret. Det vil være selve den illokutionære kraft, der på baggrund af en række markører vil lede mod en fortolkning af, at det ytrede er fiktion. Dette er overensstemmende med den kommunikative opfattelse af fiktionalitet, som Walsh beskriver som kontekstuelt bestemt. Walsh skriver: "Fiktionalitet er hverken et skel mellem to verdener eller en ramme, der adskiller forfatteren fra diskursen, men en kontekstuel antagelse fra læserens side forårsaget af den information, som forfatterens diskurs har frembudt som fiktion" (Walsh 36). Det er dermed konteksten, hvori ytringen indgår, der er det afgørende for bestemmelsen af den som fiktionaliseret. Ytringens propositionelle indhold i sætningen: "For mange år siden levede en kejser, som holdt så uhyre meget af smukke nye klæder" kan i én sammenhæng potentielt være sandt og $i$ en anden fiktionaliseret. Læseren vil, som den foreligger her, formodentlig være tilbøjelig til at tolke ytringen som værende fiktionaliseret på grund af de konventioner, der lægger sig til eventyr-/historiefortælling. Indgår ytringen i en bestemt kontekst (f. eks. en eventyrbog), der indbyder til at forstå den som fiktionaliseret, vil modtageren være endnu mere tilbøjelig til at tolke den som sådan. Omvendt kan sætningens kontekst (f. eks. en historiebog) også lede modtageren til at fortolke den som værende sand. Det kan dog også, modsvarende det, Searle fremdrager om talehandlingernes funktions-indicerende markører, være markører uden for den institutionelle eller genremæssige kontekst såsom ordfølge, tryk, intonationskontur mm., der leder fortolkningen i én bestemt retning.

Denne artikel vil derfor tale for, at det hviler på den fortolkningsrespons, ytringen inviterer til, om noget anskues som fiktionaliseret. Det skal dog samtidig pointeres, at der kan udledes endnu en konsekvens af en kontekstuel forståelse af 
fiktionalitet: Der kan forekomme tilfælde, hvor det propositionelle indhold kan lede til en revurdering af konteksten. Hvis der i en historiebog står, at kejser Napoleon ofte gik rundt i gaderne uden tøj på, vil de færreste være tilbøjelige til at tolke det som en sand ytring. I det nævnte eksempel vil strategien formodentlig være at genoverveje ytringens kontekstuelle rammer imod en antagelse om, at konteksten reelt er en historiebog, eller at pågældende afsnit ikke skal forstås inden for rammerne af den historiske korrekthed, der knytter sig til rammerne for historieskrivning. Jeg vil dermed påpege, at fortolkningen ikke blot er en envejsproces fra det kontekstuelle til en direkte prægning af fortolkningsstrategien, men en dialektisk proces mellem propositionelt indhold og kontekstuel antagelse.

Endnu et aspekt, der vedrører den indirekte talehandling, må fremhæves. Searle skriver i "Indirect Speech Acts":

"Talehandlingsteorien og samarbejdsprincipperne for samtale leverer et rammeværk, hvorinden-for indirekte illokutionære handlinger kan udtrykkes og forstås. Inden for dette rammeværk vil bestemte former dog tendere til at blive konventionaliseret og etableret som standard idiomatiske former for indirekte talehandlinger" (Searle (2) 75-76).

Searle fremhæver her, at der ud over de principper, der vil lede tolkningen i en bestemt retning, også findes standardiserede idiomatiske former for indirekte talehandlinger. Dette mener jeg også gør sig gældende for fiktionalitet. Visse idiomatiske udtryk som "Der var engang" eller "For mange år siden" indbyder uden videre til, at modtager vil opfatte det ytrede som fiktionaliseret.

\section{Fordelene ved at betragte fiktionalitet som indirekte talehandling}

Betingelsen for, at fiktionalitet anskuet som en indirekte talehandling er vellykket, er, som jeg har påpeget, i første omgang, at den anerkendes som fiktion. Hvis fiktionalitet som denne artikel lægger op til, anses som en egenskab, kan fiktionalitet dog ikke i sig selv være et formål. Som Walsh påpeger i sin kritik af Genette, må fiktionalitet gøre noget mere.

Genette hævder i sin artikel, at fiktionens formål er at blive erkendt som fiktion, og derudover også, at fiktionen skaber fiktive verdener. Endelig skriver Genette i samme artikel, at det perlokutionære mål for fiktionen er æstetisk: ”Hvad angår den tilsigtede perlokutionære effekt, hvorvidt den opnås hos tilhørerne eller ej, vil jeg summarisk kvalificere den som æstetisk” (Genette 59-73). Denne sidste angivelse af fiktion peger i en uheldig retning mod kantianske bestemmelser som "kunst for kunstens egen skyld", hvilket ligger fjernt fra den kommunikative fiktionalitetstilgang, der her er tilstræbt. Som påpeget leder Genettes bestemmelse til, at han definerer fiktion negativt i forhold til andre talehandlinger. Genette skriver: "Den specifikke egenskab ved fiktionelle ytringer er, at de i modsætning til virkelige 
ytringer (utterances of reality), der i tillæg (!) beskriver en tilstand af objektive fakta, ikke beskriver andet end en mental tilstand” (Genette 59-73). Med udråbstegnet understreger Genette, at fiktionaliserede ytringer er begrænsede i forhold til dem, det vedrører "virkeligheden”. Ytringer, der omhandler "virkeligheden", beskriver ifølge Genette både objektive fakta og mentale tilstande, mens fiktion kun formår det sidstnævnte.

Richard Walshs bestemmelse af fiktion går i diametral modsat retning. Walsh skriver:

"Fiktioner ses ikke længere som fortællinger med bestemte regler (om reference), der stilles i bero. I stedet ses ikke-fiktive fortællinger som fortællinger under bestemte tillagte restriktioner (konnoterende historicitet, objektivitet osv.), der har til formål at etablere en sanddruelighedsretorik" (Walsh 39).

Dermed vender Walsh problemstillingen om og peger på, at det er de ikke-fiktionaliserede fortællinger i stedet for de fiktionaliserede, der er begrænsede. Walshs karakteristik i citatet angår fiktionaliserede fortcllinger, og jeg er enig i, at ikkefiktive fortællinger kan anses som begrænsede i forhold til dem, der indeholder fiktionaliserede elementer. Dog mener jeg, det er vigtigt at fastholde, at fiktionalitet anskuet som en indirekte talehandlingstype er en sarlig form for udtryksmåde. Som indirekte talehandling indebærer fiktionalitet en særlig underliggende talehandling, der herved adskiller den fra de assertive talehandlingstyper. Det er netop i kraft af, at fiktionalitet er en undtagelse fra direkte ytringer, at den kan anskues som en særlig egenskab.

For at tilnærme mig, hvad fiktionens mer-formåen indebærer, vil jeg vende tilbage til udgangspunktet. Searle skriver i "Language in society", at der kun er fem ting, vi kan foretage os gennem sprog, hvilket er knyttet til de fem forskellige talehandlingstyper: (I) vi fortæller mennesker, hvordan ting er gennem assertiver, (2) vi prøver på at få andre mennesker til at gøre ting gennem direktiver, (3) vi pålægger os selv at gøre ting gennem kommissiver, (4) vi udtrykker vores følelser og attituder gennem ekspressiver og (5) vi skaber forandringer med vores ytringer gennem deklarationer (Searle (3)). Searle skriver om de indirekte talehandlinger, at de er i stand til at performe flere af disse funktioner på én gang (Searle (2) 7I). Det mener jeg også er tilfældet for fiktionalitet. Fiktionaliserede udsagn udtrykkes gennem brug af assertiver ligesom direkte udsagn fremsat om den virkelige verden, men indebærer indirekte de egenskaber, der er knyttet til deklarative talehandlinger. Den deklarative talehandlings funktion er, som Searle skriver, at den er i stand til at indstifte nye overenskomster mellem mennesker i en social verdens kontekst såsom ægteskab og dåb. Det er det samme, der gør sig gældende for fiktionalitet, der indstifter nye forhold i en kommunikativ sammenhæng afhængig af en fælles overenskomst mellem afsender og modtager. Uden for en social kontekst har ægteskab og dåb ingen reel værdi, og på lignende vis må også fiktionalitet tolkes ind $\mathrm{i}$ en social kontekst for at have gyldighed som fiktionalitet. 


\section{Afsluttende betragtninger: Hvad vindes ved at anskue fiktionalitet som indirekte talehandling?}

Slutteligt fortjener spørgsmålet om, hvad man vinder ved at betragte fiktionalitet som en indirekte talehandling, at blive behandlet. Modtagerforhold er, som jeg har gjort opmærksom på, afgørende, når det gælder indirekte talehandlinger, og jeg mener, disse med fordel kan overføres til de, der gør sig gældende for litteratur.

Der er de senere år foregået et spil mellem opfattelser af "fiktion” og "ikkefiktion" og sammenblandingen af begreber som værk, forfatter, fiktion og biografi, der tidligere er blevet anset som forholdsvist afgrænsede kategorier. Disse spil har været italesat i stor stil både gennem litterære værker og teoretiske diskussioner (Kjerkegaard, Nielsen og Ørjasæter). Bøger som Das Beckwerks, Knud Romers Den som blinker er bange for døden, Karl Ove Knausgårds seksbindsværk Min Kamp for bare at nævne nogle få af de mange, der har været debatteret, leger netop med fiktionalitetens i mange tilfælde uafgørlige forhold. Fiktionalitetens uafgørlighed i megen litteratur kan forklares gennem fiktionalitet anskuet som en indirekte talehandlingstype, fordi den ikke er entydig og opfattelsen af den derfor modtagerafhængig. I flere nyere værker er tvetydigheden $\mathrm{i}$ fortolkningsstrategien det intenderede. Det er i kraft af, at afkodningen af en indirekte talehandling er kontekst- og modtagerafhængig, at sådanne tvetydige spil kan finde sted.

I forlængelse af Richard Walsh vil jeg tale for en kommunikativ tilgang til fiktionalitet, der ikke kun er knyttet til litterære repræsentationer, men bruges som virkemiddel i mange medier (Se bl.a. Walsh (I)). Min argumentation for, at fiktionalitet kan beskrives som en indirekte talehandling, er derfor ikke et ønske om at afgrænse fiktionalitet til sproglig repræsentation, men derimod at udvide ideen, der ligger bag den indirekte talehandling, til også at omfatte andre repræsentationsformer. Jeg vil dermed argumentere for, at fiktionalitet $i$ visuelle og auditive medier så vel som fiktionalitet $\mathrm{i}$ hverdagskommunikation indebærer den samme form for kommunikative gestus som fiktionalitet i litteraturen. En skuespiller udfører en direkte handling, men den skal afkodes som udtryk for en del af den rolle, skuespilleren spiller. De begivenheder, der finder sted i en spillefilm, skal på samme måde tolkes som udtryk for fiktionaliserede handlingsdele. Kun hvis modtageren er i stand til at afkode, at den rolle, der spilles, eller den begivenhed, der udføres, er intenderet fiktionaliseret, er kommunikationen mellem skuespiller/ instruktør og publikum (i første omgang) vellykket.

Fiktionalitet anskuet som en seriøs kommunikativ strategi indebærer, at fiktionalitet betragtes som en form for udsagn eller dele af et udsagn rettet mod en modtager. Dette gælder i sproglige så vel som ikke-sproglige repræsentationsformer. Jeg har med artiklen ikke ønsket at insistere på, at selve termen ”indirekte talehandling” nødvendigvis er den mest dækkende for fiktionalitet, men har villet demonstrere, at den indirekte talehandlings egenskaber kan være en hjælp til at forklare, hvad der sker, når vi benytter os af og afkoder fiktionalitet. 


\section{LITTERATURLISTE}

Austin, J.L. Ord der virker (org. How to do Things with Words ((1962), 1975). København: Gyldendal, 1997. Barthes, Roland. "Forfatterens død”. Forfatterens død og andre essays. Red. Carsten Meiner. Gylling: Gyldendal, (I968) 2004.

Genette, Gérard. ”The Pragmatic Status of Narrative Fiction”. Style vol. 24.I 1990: 59-72. Web. 28. november 20II. http://web.ebscohost.com.ez.statsbiblioteket.dk).

Iser, Wolfgang. "Tekstens appelstruktur" (Oversat af Gunver Kelstrup). Vark og laser. Red. M. Olsen og G. Kelstrup. København: Borgen, (1970) I98I.

Kjerkegaard, S, H.S. Nielsen og K. Ørjasæter (red). Selvskreven. Om litterer selvfremstilling. Gylling: Aarhus Universitetsforlag, 2006.

Lanser, Susan. "The 'I' of the Beholder: Equivocal Attachments and the Limits of Structuralist Narratology". A Companion to Narrative Theory. Red. James Phelan og Peter Rabinowitz. Oxford, England: Blackwell, 2005.

Nielsen, Henrik Skov. "Fiktion, fiktionalitet og unaturlige fortællinger". Spring 3I-32- Fiktionens forandringer. Red. Reitan, Behrendt og Barlyng. Århus: Spring, 20II: 22-56.

Reitan, Rolf. "The Rhetoric of Fictionality: Introduktion til Richard Walsh". Spring 3I-32 - Fiktionens forandringer Red. Reitan, Behrendt og Barlyng. Århus: Spring, 20II: 22-56.

Searle, John R. "What is a Speech Act". Pbilosophy in America. Red. Max Black (Allen \& Unwin), London: Cornell University Press, 1965: 22I-239.

Searle, John R. "The Logical Status of Fictional Discourse". New Literary History 6 (2). Baltimore: The John Hopkins University Press, 1975 (I): 319-332.

Searle, John R. "Indirect Speech Acts". Syntax and semantics, vol. 3, Speech acts. Berkeley: University of California, 1975(2): 59-82.

Searle, John R. ”A Classification of Illocutionary Acts". Language in Society 5, (I). Cambridge: Cambridge University Press, 1976 (3): I-23.

Walsh, Richard. The Rhetoric of Fictionality. Columbus: The Ohio State University, 2007.

Walsh, Richard. "Person, Level, Voice. A Rhetorical Reconsideration". Postclassical Narratology. Approaches and Analyses. Red. Jan Alber og Monika Fludernik. Columbus: The Ohio State University Press, 2010 (I). 